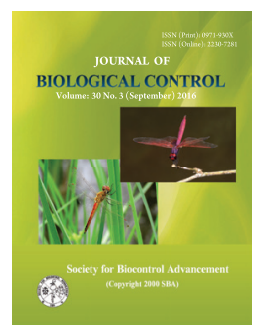

\title{
Microbial defense systems in foods and feeds
}

\author{
DJADOUNI FATIMA* \\ Department of Biology, Faculty of Natural Sciences and Life, Mascara University, Mascara - 29000, Algeria \\ *Corresponding authorEmail: Houarisalwa@yahoo.fr
}

\begin{abstract}
Bacteriocins are proteinaceous substances having antigenic and developed by some microbial strains having the ability and effectiveness against pathogenic bacteria and spoilage, harmless to the consumer, and have no adverse effect on the organoleptic product quality. Bacteriocins are rendered inactive by the action of proteolytic enzymes present in the gastrointestinal tract, thy can resist high temperatures, are non-toxic and does not compromise the immune system in experimental animals. Bacteriocins as microbial defense systems has been widely researched and documented. However, though the diversity and abundance of bactrocins is very high, indicating their use as microbial weapons, research on ecological and evolutionary significance needs elaborate studies. More advanced studies are needed to unfold reasons for their success as toxins.
\end{abstract}

KEY WORDS: Bacteriocins, foods, feeds, biopreservation, spoilage flora, pathogenic bacteria, antimicrobial potential

(Article chronicle: Received: 22-08-2016; Revised 24-09-2016; Accepted: 24-09-2016)

\section{INTRODUCTION}

Bacteriocins were first recorded in 1925, when André Gratia showed the activity of a highly specific inhibitory substance, produced by the bacterium Escherichia coli, which showed bactericidal activity against other $E$. coli strains (de Lima and Filho, 2005). It was observed that $E$. coli cells produced a temperature tolerant substance with inhibitory effect on microbials of related taxa. The presence ofantagonistic interactions among bacteria was reported by Pasteur and Joubert at the end of the $19^{\text {th }}$ century. They noticed that a bacterial isolate could inhibit the growth of Bacillus anthracis (Jack et al.,1995).The production of antibacterial substances by lactococci was also reported in 1928 by Rogers. Research findings on bacteriocins were mostly descriptive but protocols for detection, assay and bacterial strain typing have been established. (Fredericq, 1957; 1963). Pioneering work on bacteriocin genetics was studied by Fredericq $(1957 ; 1963)$. Whitehead (1933) showed that the antibacterial substance produced by lactococci was protein. The protein was concentrated and tested against pathogenic streptococci (Mattick and Hirsch, 1944) and later the same protein that was inhibitory was used to treat bovine mastitis (Taylor et al., 1949). Similarly, intersection studies showed that a Staphylococcus isolate could inhibit Corynebacterium diphtheriae. Leading to the successful utilization of Staphylococcal isolates indiphtheria treatment (Florey, 1996). The inhibitory interactions among various species of enterobacteriaceae resulted in naming with the generic name 'colicine'. Jacob et al. (1952) coined the general name bacteriocin for highly specific ribosomally synthesized antibacterial proteins differentiated from the classical antibiotics, and produced by certain strains of bacteria and active mainly against strains of the same species. Bacteriocins have since gained new attention on particularly in the epidemiology of nosocomial infections; they have been found to be very useful in typing organisms particularly those which are difficult to type by the usual methods (Lebek et al.,1993).

Further research could decipher the bacteriocin genetics, biosynthesis, secretion and mode of action (Lakey et $a l ., 1993)$. The results led to the application of bacteriocins as a biochemical tool incellular physiology (Becker et al., 1993).

\section{MICROBIAL DEFENSE SYSTEMS}

Complex array of defense mechanisms are inherently present in microbes (Riley and Wertz, 2002) which helps them to overcome infections or competition (Nissen-Meyer and Nes, 1997). Defense mechanisms adopted include expression of antibiotics with broad spectrum activity which have serious implications on human health, metabolic products like lactic acids, lytic agents ex. lysozymes (found in many foods) and extoxins (James et al., 1991). In most of 
the species the first line of defense include production of antimicrobial peptides which for part of inborn immunity (Cleveland et al., 2001). The peptides can act against a particular group of competing microbes; or it can have broad spectrum activity that can serve as a general type of defense mechanism. These peptides can act directly on all microbes including bacteria, fungi viruses causing cellular damage by destabilization of cellular membrane or other targets affecting the organization of the inflammatory and innate immune responses (Hancock and Diamond, 2000a). Antimicrobial peptides are found in virtually all forms of life, from bacteria to plants and invertebrate and vertebrate species, including mammals and aid in defense mechanisms. Bacteriocins are antimicrobial peptides produced by bacteria and belong to one family of microbial defense systems; and were the first to be isolated and characterized (Mattickand Hirsch,1947). They basically act by killing other bacteria that compete for nutrients in that same environment, however they cannot ward off infections. Most bacteria produce bacteriocins and are highly potent as compared to those produced by eukaryotes (Klaenhammer, 1988). They can have narrow or broad spectrum activity and can target bacteria within same species and but can also act on different genera. Production of bacteriocins is a universal phenomenon in the microbial world, every bacteria produce them and within a species tens or even hundreds of bacteriocin types can be seen (Riley and Gordon, 1992).

\section{ECOLOGY}

The ability to synthesize bacteriocins by bacteria has been a highly advantageous characteristic as they evolved (Chen and Hoover, 2003). If an organism can remove a competing organism in it is ecological environment then it has an excellent chance to survive and multiply, often the competition can be severe since bacteria grow rapidly (Dykes, 1995).The population dynamics of bacteriocins and their interactions are complex and ecological and evolutionary levels and much need to be unfolded.Hence bacteriocins can act as anti competitors as well as defensive agents to prevent entry of other bacteria into an established niche. Studies on Lactobacillus plantarum, E. coli, and Streptococcus mutans reveal that those that growth of bacteriocin sensitive bacteria can be inhibited when bactericin producers are present in the same environment (Riley, 1998).To ferment Spanish-style green olives L. plantaru$m$ a bacteriocin-producing strain was used. (Ruiz-Barba $e t$ al.,1994).Analytical models have been proposed and used to understand the interaction between bacteriocin producers and sensitive ones. Mathematical modelling of bacteriocins have been done by utilizing the colicins (those that are expressed by $E$. coli but show inhibition of different E. coli strains and closely related enterobacteria) Stessful conditions such as nutrient deficiency and overcrowding facilitate bacteriocins production and $30 \%$ of E. coli populations produce bacteriocins (Riley, 1998; Riley and Gordon, 1999). Riley (1998) reported that around $30 \%$ of E. coli strains can express bacteriocins.. Stress factors, depleted nutrient conditions and overcrowding are inducers for bacteriocin secretion (Riley and Gordon, 1999).

\section{DEFINITION OF BACTERIOCINS}

As more research data emerged, the true meaning of bacteriocins has undergone many changes since its discovery. Antibiotics are antimicrobial substances produced by microbes, animals, plants or by synthetic means and will have the following properties at low concentrations: i) lethal or inhibitory activity against microbial species; ii) ability to prevent the appearance of microbial resistance; iii) absence of undesirable effects to the host; and iv) chemical stability (Tavares, 1984; Amato Neto et al., 1994; Abrahan et al., 1996). In general way, antibiotics can be defined as agents of great interference on the growth and/or microbial activities (Trabulsi et al., 2002). Antibiotics can act act in different ways on the microbial cell which can bei) damaging the cell wall; ii) destabilizing the cytoplasmic membrane; iii) changing the nucleic acid structure; iv) inhibiting the enzymatic action; v) antimetabolic action; and vi) affecting the acid nucleic synthesis (Pelczar et al., 1980).

Tagg et al. (1976), defined bacteriocins as proteinaceous substances that kill closely related bacteria. This definition is true for the majority of bacteriocins investigated, but evidences show that certain bacteriocins can elicit bactericidal activity against species that are more distantly related to the bacteriocin producer. Bacteriocins are produced by gram positive and gram negative bacterial species and have the capacity to inhibit closely related species at low concentrations (Riley, 1998; Brock 1995). De Vuyst and Vandame (1994) have worked out the heterogeneity of bacteriocin producing-bacterial species, their molecular size, antibacterial spectrum, stability, physical and chemical properties, and action mode. The protein nature and absence of lethality to producer cells are considered as two factors for the definition of bacteriocins (Montville and Kaiser,1993).

Bacteriocins are often designated as antibiotics in literature (Hansen, 1993). Mode of action, basis of synthesis, antimicrobial spectrum, toxicity, resistance mechanisms, and applications and clinical effects differentiate from antibiotics(Table1) (Klement et al., 1990; Davis, 1999). Antibiotics (Chen and Hoover, 2003) are to be safely and effectively used to control the growth of target pathogens in foods (Table 1). 
Table 1. Bacteriocin vs. antibiotics (Klement et al., 1990)

\begin{tabular}{lll}
\hline Characteristic & bacteriocins, & Antibiotics \\
\hline Application & Food & Clinical \\
Synthesi & Ribosomal & Secondary metabolite \\
Activity & Narrow spectrum & Varying spectrum \\
Host cell immunity & Yes & No \\
Mechanism of target, cell resistance & Usually adaptative on affecting cell & Usually a genetically transferable deteminant affect- \\
or tolerance & membrane composistion & ing different sites depending on the mode of action \\
Interaction requirements & Sometimes docking molecules & Specifie target \\
Mode of action & Mostly pore fomation, but in a few & Cell membrane or intracellular targets \\
& cases possibly cell wall biosynthesis & \\
Toxicity/side effects & None known & Yes \\
\hline
\end{tabular}

\section{Antimicrobial peptides from eukaryotes}

Antimicorbial peptides play a basic and crucial role in defence against bacterial and fungal interactions in plants (Jensen et al., 2006). For instance, plant defensins display antibacterial and antifungal activities in vitro (Terras et al.,1992). Leaves, flowers, seeds, and tubers are found to harbour such defensins. Antimicrobial peptides which have an imminent role in host defense were isolated from vertebrates and invertebrates. It is shown that amphibian skin glands are rich source of antimicrobial peptides. For example Magainins (Zasloff, 1987) present in amphibian skin glands have strong membrane-permeabilizing activity against gram-positive and negative bacteria, fungi, yeasts, and viruses. Similarly cathelicidins are a large and diverse group of vertebrate antimicrobial peptides. Defensins form a another prominent group of mammalian antimicrobial peptides (Ganz,2003). Tsai and Bobek (1998) observed that histatin a bacteriocin secreted in saliva of humans and primates is known to act against fungal pathogens by disrupting the mitochondria

\section{Antimicrobial peptides from bacteria}

Antimicrobial peptides have been produced and detected in all lineages of eubacteria and archaebacteria (Torreblanca et al., 1995). It is now understood that almost all bacteria are able to express at least one bacteriocin and researchers need to look for them (Klaenhammer, 1988). Expression of these antimicrobial peptides requires considerable amount of energy. Various environmental conditions, including $\mathrm{pH}$, temperature, aeration, sugar concentration, buffering capacity of the medium and time of incubation, affect the production of bacteriocins (Lewus, 1991) to bacteriocins, thus the physiological status can determine effectivity (Tag et al., 1976).

\section{Bacteriocins of gram positive bacteria}

As discussed previously $99 \%$ of bacteria produce bacteriocins (Klaenhammer, 1988) and are generally extremely potent as compared to those produced by the eukaryotic counterparts. Gram positive bacteria are able to produce the most active membrane peptides (Oscáriz and Pisabarro, 2001). Presently bacteriocins produced by gram-positive bacteria are the most studied group of antibacterial peptides, given their potential for commercial applications in foods and other products (Schillinger et al., 1996) as they can show either narrow or broad spectrum activity. Grampositive bacteria produce bacteriocins with broad spectrum activity when compared to gram-negative bacteria, and these bacteriocins are active against both gram-positives and also a few of the gram-negatives. Specific immunity by a producing strain is less strong, probably the bacteriocins produced by gram-positive bacteria do not bind to a specific receptor protein but with the phospholipid head groups of the membrane. The gram-positive bacteriocins are generally of the channel-forming type and not the nuclease type. Most of these bacteriocins are small (less than $5 \mathrm{KDa}$ ), heat stable, amphiphilic, membrane-permeabilizing peptides, cationic proteins that are structurally unlike the colicins. Most are synthesized as prepeptides in which the leader peptide is removed to form the biologically active bacteriocin. These features show similarities in production of antimicrobial peptides by eukaryotes (Jon Nissen and Ingolf, 1997). Bacteriocins produced by lactic acid bacteria (LAB) have been widely studied, of which sakacins are unique (Jack et al., 1995), including the lantibiotics that have altered amino acid residues (Oscáriz and Pisabarro, 2001) are important. Bacteriocins of LAB are mostly categorized into 3 groups that also include bacteriocins from other grampositive bacteria (Klaenhammer, 1993; Nes et al., 1996). Guder et al. (2000) observed that lantibiotics or lanthionine based antimicrobial peptides are small $(<5 \mathrm{KDa})$ peptides and contains lanthionine (Lan), methyllanthionine (MeLan), dehydroalanine, and dehydrobutyrine which are unusual amino acids. Lantibiotics come under class I group and are further classified as type A and type B lantibiotics based on chemistry and antimicrobial activity Cleveland $e t$ al. (2001) have classified the lantibiotics as Type A (elongated peptides havinga net positive charge) and Type B lan- 
tibiotics are (smaller globular peptides and have a negative or no net charge; and are able to inhibit specific enzymes). Small ( $<10 \mathrm{KDa})$, heat-stable, non-lanthionine-containing peptides are contained in class II (Cleveland et al.,2001), which represents the largest group of bacteriocins. These peptides are divided into 3 subgroups. Class IIa includes pediocin-like peptides having an $\mathrm{N}$-terminal consensus sequence -Tyr-Gly-Asn-Gly-Val-Xaa-Cys. This subgroup has attracted much of the attention due to their anti-listerial activity (Ennahar et al., 2000). Class IIb contains bacteriocins requiring 2 different peptides for activity, and class IIc contains the remaining peptides of the class, including sec-dependent secreted bacteriocins. Bacteriocins grouped under class III are larger $(>30 \mathrm{KDa})$ proteins and heat-labile. Klaenhammer (1993) suggested 4th class bacteriocins that act on carbohydrate or lipid moieties however, this needs biochemical characterization with more description (McAuliffe et al., 2001). Nisin, a lantibiotic, produced by Lactococcus lactis, a food preservative did not show any resistance development But extremely active against grampositive bacteria at mininmal inhibitory concentrations (MICs) and activity can be seen nanomolar levels. Other lantibiotics have found their important role in combating antibiotic resistant bacteria. A notable example is mersacidin, a tetracyclic peptide produced by Bacillus spp. which can suppress methicillin- resistant $S$. aureus and is comparable with vancomycin, but without the development of cross resistance (Chatterjee et al., 1992a and 1992b;Kruszewska et al., 2004).

\section{Bacteriocins of gram negative bacteria}

The bacteriocin family is made up of diverse proteins that vary in size, modes of action, target organisms, and immunity mechanisms. Recombination between existing bacteriocins produce gram-negative bacteria produced bacteriocins (Braun et al., 1994). The killing actions of colicins include pore formation in the cell membrane, and nuclease activity against DNA, rRNA, and tRNA targets.

Gram-negative bacteria produce bacteriocins that have large molecular size. Colicins the largest representative of gram-negative pore forming bacteriocins, range in size from 449 to 629 amino acids. Colicins expressed by E.coli are encoded on plasmids (Pugsley and Oudega, 1987) and genes for bacteriocins of Serratia marcesens which are also similar to colicins are located on both plasmids and genomic DNA (Ferrer et al., 1996). In colicins, the central domain is composed of half the protein and is involved in the recognition of specific cell surface receptors. The $N$-terminal domain ( $>25 \%$ of the protein) translocates the protein into the target cell. The killing domain and the immunity region, form part of the remaining colicin protein which is a short sequence and takes part in immunity protein binding. Pyocins produced by Pseudomonas aeruginosa are also similar to colicin structure but the order of translocation and receptor recognition domains are switched (Sano et al., 1993).

\section{Antimicrobial peptides from archaebacteria}

Archaeocins are bacteriocins expressed by archaeabacteria and are unique. The only characterized member is from the halocin family produced by halobacteria (Cheung et al., 1997; Shand et al., 1998). S8 is the first discovered halocin and is composed of a short hydrophobic peptide with 36 amino acids, this is derived from larger pro-protein of $34 \mathrm{KDa}$ (Price and Shand, 2000). The gene for Halocin S8 is located on a megaplasmid and is very hardy; as it can be desalted, boiled, resistant to to organic solvents, and can be stored at $4 \pm^{\circ} \mathrm{C}$ for long period without loss of activity. The gene expression depends upon the growth stage. Halocin S8 can exist at low concentrations at basal level but during transition to stationary phase explosive nine fold increase in secretion can be noticed. Archaeocins are expressed during stationary phase wherein availability of nutrients are limited, the bacteriocin can lyse sensitive cells which in turn make available nutrients in the local environment. Archaeocins are stable proteins, and tend to remain in the environment for extended periods thereby reducing competition during subsequent phases of nutrient flux. This property enables lesser species diversity in the hypersaline environments dominated by halobacteria (Riley et al., 2002; Shand et al., 1998).

\section{NOMENCLATURE}

Bacteriocin nomenclature in general is is based on the addition of the suffix "cin" to the genus or species name to denote bacteriocinogenic activity. However in some it's based on the species (plantaricin, sakacin, caseicin) or genus name (lactococcin, lactocin, pediocin) of the producer microorganism (de Lima and Filho, 2005). Lactostrepsinn nisin and diplococcin refer tobacteriocins produced by different Lactococcus species. Alphabetic sequence used to refer the discovery sequence of the same species for eg lactacin $\mathrm{F}$ refers to the sixth bacteriocin reported for a $\mathrm{Lac}$ tobacillus species (Tagg et al., 1976; Kozar et al., 1978, Klaenhammer, 1988; Montville and Kaiser, 1993). Tagg et al. (1976), called bacteriocin-like inhibitory substances (BLIS) or antimicrobial substances that are less understood. McCormick and Savage (1983) used the same term to refer all inhibitory substances of a protein nature. It was evident that the nomenclature for bacteriocins was mired in controversy since a single species can produce more than one bacteriocin, and hence can be called by the addition of 
consecutive letters of the alphabet. Some authors use name of producer strain apart from normal bacteriocin designation (Montville and Winkowski, 1997). So the fact remains that naming of bacteriocins were not in proper order for example six independently isolated bacteriocins were given six different classifications but which were later proved to be the same substance based on their amino acid sequences. Such discrepancies in bacteriocin classification can impair advances in research on bacteriocins (Montville and Winkowski, 1997). Hence Jack et al. (1995) opined that a new name should only be designated to a bacteriocin after identification of the amino acid sequence.

\section{CLASSIFICATION OF BACTERIOCINS}

Taxonomy of bacteriocins have been dynamic and many nomenclatures have been proposed over the years Fredericq (1957) proposed the primary classification on colicins Colicins were grouped based on the absorption specificity as bacteriocins have a high degree of specificity. of their adsorption and subgroups were proposed based on immune specific reactions.. Also based on spectrum of resistance several bacteriocins were further subdivided. In 1965 Reeves could classify 16 bacteriocins based on the source or the organism that produced it. Hence colicins are bacteriocins produced by E. coli, pyocin produced by Pseudomonas. aeruginosa (, cloacin expressed by Enterobacter cloacae, pestisin from Yersinia pestis, monocin of Listeria monocytogenes, Bacillus cereus based cerecin, and staphylococcin secreted by Staphylococcus (Daw and Frederick, 1996). Hence Bradely (1967) Based on molecular weight Bradely (1967) could classify bacteriocins into two distinct groups viz., low and high. The low molecular weight ones are thermostable and are not sedimented by ultracentrifugation, and is unresolved through electron microscope. Those grouped as having high molecular weight can be easily sedimented, are thermolabile, show trypsin resistance and resolved through electron microscope. The classification based on molecular weight enables the inclusion of bacteriocins produced by Bacillus sp. The low molecular weight bacteriocins can be compared to phage particles (Bradley, 1966). Gram positive bacteria produce bacteriocins that do not conform to the strict definition of bacteriocin because (1) they broad spectrum activity against gram positive species, (2) specific receptors are involved in heir mode of action and (3) lysins can enhance their release (Daw and Frederick, 1996). Hence it was suggested that (Havarstein et al., 1994) the bacteriocins produced by gram positive bacteria be grouped differently, also since they lack the outer membrane, the immunity shown to their own bacteriocins are varied. Tagg (1992) opined that a new definition is needed for bacteriocins as some of the recently reported peptides are different from colicins, however the original definition can be retained with peptides similar to colicins grouped as BLIS. Gram positive bacteria do have a relatively high BLIS production. Biochemical (net charge) and/ or structural features (linear/circular/amino acid composition) are major criteria for classification of antimicrobial peptides (Tossi and Sandri, 2002; Zasloff, 2002). Jack et al.(1995) suggested that the presence of disulphide and monosulphide (lanthionine) bonds be the basis for bacterioicin classification and it can be used as a benchmark to denote $r$ their spectrum activity, since presence of higher number of the disulphide bonds in a bacteriocin enhances the activity spectrum. Hence, bacteriocins can form four taxonomic groups: A antibiotics having unusual post translationally modified amino acids such as dehydroalanine, dehydrobutirine, lanthionine or - methyl- lanthionine (lantibiotics), B. antibiotics containing at least one disulphide bridge essential for their activity (cystibiotics), C. peptides containing single $-\mathrm{SH}$ residue that are in a reduced form which enables the antibiotic to be active (thiolbiotics), and D. peptides lacking the cysteine residues (Table 2). Klaenhammer (1993), classified bacteriocins into 4 groups based on their molecular mass, thermostability, enzymatic sensitivity, presence of post translationally modified amino acids, and mode of action.

\section{Class I bacteriocins}

The Class I bacteriocins comprises lantibiotics and can be further divided into two subgroups on the basis of structure and charge of the compound:

- Group Ia, which consists of screw-shaped, amphipathic, small cationic peptides that produce voltage-dependent pores by unspecific interaction with the membrane of the target cell.

- Group Ib, which consists of anionic or neutral peptides having a globular shape.

The number of thioether bridges (modified amino acids) present in group Ia lantibiotics can vary and members with either three (pep5) (Reis et al., 1994), four (epidermin) (Allgaier et al., 1986), or five (nisins A and Z, subtilin) (Hurst, 1978; Banerjee and Hansen, 1988) monosulfide bonds have been described. The molecular size of these antibiotics ranges from 1,959 (duramycin) to 4,635 (carnocin U149, the largest lantibiotic described up to now) (Nes and Tagg, 1996). Group Ib includes antibiotics such as mersacidin (Chatterjee et al.,1992b), actagardin (Jung, 1991), cinnamycin and mutacin A (Kaletta et al.,1991).

\section{Class II bacteriocins}

The Class II bacteriocinsare composed of heat-stable 
peptides with molecular masses smaller that $10 \mathrm{KDa}$ and with no modified amino acids. Members of this class can be further subdivided into three groups:

- Group II a consists of antilisterial peptides including pediocin, mesentericin, sakacin, and carnobacteriocin. These compounds are bactericides that disrupt the integrity of the cytoplsamic membrane, producing ionic imbalance and leakage of organic phosphate to exert their killing action.

- Group II b consists of pore-forming complexes requiring two peptides for their activity. The two peptides are individually active but when present together they behave synergistically (Cintas et al., 1998), or they may both be necessary for antimicrobial activity (lactococcins) (Nissen-Meyer et al., 1992), and plantaricins (Van Belkum et al., 1991).

- Group II c includes all class II bacteriocins that do not fall into groups IIa or IIb. This group includes: a- antibiotics with one or two cysteine residues (thiobiotics and cystibiotics, resopectively), and b- antibiotics without cysteine (lactococcin A and acidocin B).

Table 2. Antibiotic peptides classified according to Jack et al. (1995)

\begin{tabular}{|c|c|c|c|}
\hline Antimicrobial peptide & $\begin{array}{c}\text { Molecular mass } \\
(\mathrm{KDa})\end{array}$ & Aminoacids & Producer microorganism \\
\hline \multicolumn{4}{|l|}{ Lantibiotics } \\
\hline Actagardine & 1.9 & & \\
\hline Ancivenin & 2.0 & 19 & Actinoplanes spp. \\
\hline Cinnamycin & 2.0 & 19 & Streptomyces spp. \\
\hline Duramycin & 2.0 & 19 & Str. cinnamoneus \\
\hline Epidermin & 2.0 & 19 & Str.cinnamoneus \\
\hline Gallidermin & 2.0 & 22 & S. epidermidis \\
\hline Lanthiopeptin & 2.0 & 22 & S. gallinarum \\
\hline Mersacidin & 1.8 & 19 & Streptoverticullum cinnamoneum \\
\hline Nisin & 3.4 & 19 & Bacillus sp. \\
\hline Pep5 & 3.5 & 34 & Lactococcus lactis \\
\hline Subtilin & 3.3 & 34 & S. epidermidis \\
\hline Cystibiotics & & 32 & B. subtilis \\
\hline \multicolumn{4}{|l|}{ Pediocin AcH/PA1 } \\
\hline Leucocin A/UAL 187 & 4.6 & 44 & Pediococcusacidilactici H/PAC 1.0 \\
\hline Mesentericin Y 105 & 3.9 & 37 & LeuconostocgelidumUAL 187 \\
\hline Sakacin A & 3.8 & 37 & L.mesenteroides Y 105 \\
\hline \multicolumn{4}{|l|}{ Sakacin P } \\
\hline Lactacin F & 4.3 & 41 & Lactobacillussake LB 706 \\
\hline Carnobacteriocin A & 4.4 & 43 & L.sake LTH 674 \\
\hline Carnobacteriocin BM1 & 5.6 & 57 & L.acidophilus 11088 \\
\hline Carnobacteriocin B2 & 5.1 & 53 & Carnobacteriumpiscicola LV 17 A \\
\hline Cerein $7 / 8$ & 4.5 & 43 & C. piscicola LV 17 B \\
\hline \multirow[t]{2}{*}{ Thiolbiotics } & 4.9 & 48 & C. piscicola LV 17 B \\
\hline & 4.9 & & B.cereus $\mathrm{Bc} 7$ \\
\hline \multirow{4}{*}{$\begin{array}{l}\text { Lactococcin B } \\
\text { No cysteine } \\
\text { Lactococcin B }\end{array}$} & & 56 & \\
\hline & & & \\
\hline & & & \\
\hline & 5.3 & 47 & L. lactis subsp. cremoris 9 B4 \\
\hline Lactococcin $\mathrm{M}^{\mathrm{a}}$ & & & L. lactis subsp. cremoris 9 B4 \\
\hline Lactococcin $\mathrm{N}^{\mathrm{a}}$ & 5.8 & 54 & L. lactis subsp. cremorisLMG 2130 \\
\hline Lactococcin $\mathrm{G} \alpha^{\mathrm{a}}$ & & & L. lactis subsp. lactis bv, diacetylactis WM4 \\
\hline \multirow[t]{9}{*}{ Lactococcin $\mathrm{G} \beta^{\mathrm{a}}$} & & & L. lactis subsp. cremoris 9 B4 \\
\hline & & & L. lactis subsp. cremoris 9 B4 \\
\hline & & & L. lactis subsp. lactisLMG 2081 \\
\hline & & & L. lactis subsp. lactisLMG 2081 \\
\hline & 4.3 & & \\
\hline & 4.4 & 48 & \\
\hline & 4.3 & 47 & \\
\hline & 4.1 & 39 & \\
\hline & & 35 & \\
\hline
\end{tabular}

a These two pairs of peptides act synergistically 


\section{Class III bacteriocins}

Class III bacteriocins are having peptidic antibiotics that are heat labile proteins with a molecular mass larger than $30 \mathrm{KDa}$. They are mostly produced by the genus Lactobacillus. Members of this group are leviticin J (Joerjer and Klaenhammer, 1986), produced by L. helveticus 481 and lacticin B (Barefoot and Klaenhammer, 1984), and produced by $L$. acidophilus.

\section{Class IV bacteriocins}

This group consists of either glycoproteins (lactocin 27) (Upreti and Hinsdill, 1975) or lipoproteins (lacstrepcins) (Kozak et al., 1977) that require non-protein moities for their activity.

\section{SYNTHESIS AND TRANSPORT OF BACTERIOCINS}

Siezen et al. (1996) has reviewed the genetic determinants responsible for the synthesis of bacteriocin molecules. Bacteriocin expressing genes are located in operon clusters. The lantibiotic synthesis operon has been studied in detail and genes that are homologous can be found among the many of the sequenced lantibiotic operons. Lantibiotic operons that come under Class Ia have been well characterized. Whole gene clusters for the Class $\mathrm{Ib}$ lantibiotic mersadicin have been well documented (Altena et al., 2000). It is not surprising that most of the genes in the cluster transcribe proteins that resemble the proteins in Class Ia. Plasmids of varying sizes also code for bacteriocins for example pediocinin produced by Pediococcus and lactocin produced by L. lactisare plasmid borne. Some are encoded by chromosomal DNA (Altena et al., 2000) such as plantaracin A and sakacina 674, some can be transposon regulated (Engelke et al., 1992) like produced by L. lactis (Ray, 1996). Genes coding for the structural peptides are typical to organisms (Rauch and de Vos, 1992), genes for processing of proteins to the active form (Engelke et al., 1992), proteins that aid in the transport of peptides across the membrane (Klein et al., 1992; Klein et al., 1993; Engelke et al., 1994; Klein and Entian, 1994) and peptides that help the host in conferring immunity (Diep et al., 1996; Qiao et al., 1996). The genetics of plantaricin, pediocin and sakacin that are nonlantibiotic bacteriocins have been well documented (Marugg et al., 1992; Diep et al., 1994; Ehrman et al., 2000). Lantibiotic genes share similarities with regulatory, structural, translocation, genes, etc.., plantaricin encoding genes can also code for multiple bacteriocins which share the transport and the regulatory systems. Diep et al. (1996) reported that every bacteriocin can regulate the immune system with its own dedicated genes to Bacteriocins under Class I are post-translationally modified to produce the active form while all other classes of bacterio- cins are ribosomally synthesized, (Cleveland et al., 2001; Kupke and Gotz, 1996). Genetic manupulation can help in better understanding of active sites and structure function relationship. Since structural genes code for bacteriocins their location is well Jack et al. (1995) showed that the structural genes are located in an operon, and is directly involved in the modification and translocation of peptides via the cytoplasmic membrane system of prokaryotes (Jack et al., 1995). Modern biotechnology tools can aid in synthesis of bacteriocin analogues having enhanced activity or with changed specificity that needs further design and testing, whereas in antibiotics, they need to be chemically synthesized and genetic mnupulation becomes complex due more number of genes involved.

Lysis or kill protein is the term used for one gene coding for bacteriocin release protein (BRP) which is involved in export (Havarstein et al., 1994). These freely secreted proteins are translocated and gets accumulated in the cytoplasm in a soluble form before release. Entry of bacteriocin molecule into the bacterial cell is in the form of an inactive peptide having an $\mathrm{N}$-terminal leader and a $\mathrm{C}$-terminal propeptide. Specific peptidases dissolve the $\mathrm{N}$-terminal leader for activation and release into the environment. Klaenhamer, (1993) has however, observed that at $\mathrm{pH} 5.0$ and above certain bacteriocins above remain adsorbed on the producing-cell surface. These peptides possess a positive charge and tend to form aggregates.

\section{CHARACTERISTICS OF BACTERIOCINS}

\section{Protein structure of bacteriocins}

Limited reports are available on the physical structure of bacteriocins. To determine the protein nature of bacteriocins many workers

(Daw and Falkiner, 1996; Daw and Frederick, 1996) used proteolytic enzymes to degrade crude preparations and determined their molecular weights based on diffusibility of the lysates through agar or semipermeable membranes (Daw and Falkiner, 1996; Daw and Frederick, 1996). Jack et al. (1995) observed that cationic, neutral and anionic type of bacteriocins fall in the range of 1.9 (Actagardine) and 5.8 (Lactococcin B) KDa in molecular mass. Protein or peptide component of bacteriocins are crucial for their bactericidal function, and some are synthesised as combinations of different proteins (Allison et al., 1994) or some bacteriocins can exist as composites of proteins having lipid or carbohydrate moieties (Lewus et al., 1992). Research studies by several workers (Kingsbury, 1966; Reeves, 1972;Daw and Falkiner, 1993; Daw and Frederick, 1996) has shown that bacteriocins are made up of protein molecules having traces 
of carbohydrates (less than 1\%) and phosphorus (less than 0.1\%). Others (Konisky and Richard, 1970; Howards et al., 1989; Nieto-Lozano et al., 1992; Koebink and Braun, 1993) have shown that variations in sequences or cross composition of amino acids exist among the bacteriocin molecules and varies from one bacteriocin to another, even among the same group of bacteriocins. Sahl (1994) could report that bacteriocins that were earlier considered as high molecular weight are now proved that they are small peptides this was possible due to advancement in protein purification protocols and their higher weight were attributed to high hydrophobicity and also due to co-purification along with other cellular components. Vaughan et al. (1992) earlier reported that some gram-positive bacteria could form relatively high-molecular-weight, heat-labile bacteriocin-like substances but these were later identified as small, heatstable cationic peptides structurally different from colicins. Studies by Pugsley, (1984a) revealed that colicins have a mass of 29 to $90 \mathrm{KDa}$ with receptors for specificity, translocation, or killing activity. Sano et al. (1993) later found that pyocins secreted by $P$. aeruginosa have similar domain constructs. Bacteriocins produced by gram-positive bacteria appear supposed to have been formed initially as prepeptides and later separated from the main peptide to form the biologically active molecule. In lantibiotics for example (Jung and Sahl, 1991), modifications are brought out into the propeptide region of the precursor molecule before cleavage of the leader component. Clusters of positively charged amino acids may have a role in the initial interaction with the negatively charged phospholipid head groups in the cytoplasmic membrane of sensitive bacteria (NissenMeyer et al., 1992). The unusual amino acid residues (e.g., lanthionine and b-methyl lanthionine in lantibiotics) (Jung and Sahl,1991) present in some bacteriocins may function to produce a more stable moiety. The biological activity of molecules increase when amino acid residues like Didehydroalanine, didehydrobutyrine, and cysteine provide reactive groupings Didehydro- residues of lantibiotics have been suggested to play important roles in the interaction of these molecules with the sulfhydryl groupings on germinating spores (Morris et al., 1984). The activity of thiolbiotics (eg lactococcin B) is attributed to reduction of - $\mathrm{SH}$ group of cysteine (Venema et al.,1993), similar to that of the -SH in thiol-activated toxins (Boulnois et al.,1991).

\section{Bacteriocinogeny and lysogeny}

Daw and Falkiner, (1993) observed structural similarities were noticed between bacteriocins and bacteriophages Alatossava, (1994) could later show that the similarities were because of existence of receptors thst were common to bacteriophages and colicins. Electron microscopy studies had also revealed similarities between the two antibacte- rial agents (Daw, 1989; Daw and Falkiner, 1993). Daw and Frederick, (1996) considered bacteriocins as incomplete phages as can be seen in their physical structure (Fig. 1a and b) due the high resemblance of phage tails to the bacteriocin particles.

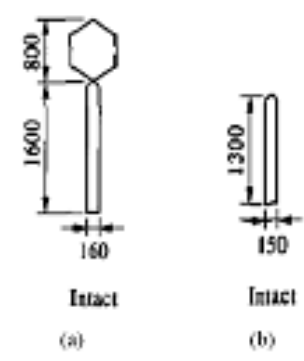

Fig. 1. Morphological comparison of a) phage PS3 and b) Rtype pyocin of $P$. aeruginosa. The phage tail is slightly larger than the bactertiocin particle. Dimensions are shown in Á. (Adapted from Daw, 1989).

The physical structure of bacteriocin resembles a headless phage and gets adsorbed to similar specific receptors present on the cell wall of bacteria before entry and kill. Ito et al. (1970) could earlier show that common receptors exist for colicin $\mathrm{K}$ and tail of phage $\mathrm{T} 6$ or colicin $\mathrm{E}$ and phage BF23. Lysogenic and bacteriocinogenic bacteria are usually immune to the antibacterial agents they produce or carry. UV irradiation can increase the production of bacteriocin and bacteriophage. Each phenomenon, however, is a lethal process for the bacterium. Mechanisms involved for bacteriocin synthesis or prophage induction are similar. This was shown by several workers (Hardy and Meynell, 1972a and b; Issacson and Konisky, 1974; Hardy, 1975; Boemare et al.,1992) wherein chemical treatments for inhibition of DNA synthesis triggers prophage induction as well as synthesis of bacteriocins. Bacteriophages are self reproducible in sensitive bacteria whereas bacteriocins are unable to do so ( (Ito and Kageyama, 1970). Some studies (Daw, 1989) indicated that bacteriophages, upon dilution, exhibit decreasing number of discrete phage plaques; whereas a bacteriocin gets diffused with increased dilution of supernatant ((Daw, 1989). There is no antigenic similarity between bacteriocins and bacteriophages. No connection could be demonstrated and a bacterium is both lysogenic and bacteriocinogenic (Daw and Falkiner, 1993; Daw and Frederick, 1996).

\section{Mode of action}

Several experiments conducted by Nomura (1967) revealed the mode of action of bacteriocins. The interaction with the bacterial cell membrane usually determines the activities of antibacterial peptides (Hancock and Rozek, 2002). Interaction is established by adsorption between 
the peptide and the target cell, this is facilitated by electrostatic bonding between the cationic peptide and negatively charged molecules of the outer bacterial envelope, such as phosphate moieties of lipopolysaccharides of gram-negative bacteria or lipoteichoic acids occurring on surfaces of gram-positive bacteria. Specific receptors present on the target microbial cell surface serve as primary ignition for biological action of bacteriocins and as a consequence result in the death of the microbial cell in an isolated or concomitant (Brashears et al., 1998). While several nonlantibiotic bacteriocins require a protein receptor to act on non-energized membranes (Montville and Winkowski, 1997), lantibiotic bacteriocins act on energized membranes and do not require protein receptors. Montville et al. (1999) could show that nisin a lantibiotic bacteriocin that is active against strains of Lactococcus, Streptococcus, Staphylococcus, Listeria and Mycobacterium, as well as spore-producing vegetative cells of Bacillus and Clostridium does not require receptors. In vitro studies revealed that the mechanism of action is probably due to pore formation (Montville et al., 1995).

Recently Jenssen et al. (2006) proposed two modes of action that enables membrane permeabilization; the formation of a complex with membrane components, leading to pore formation, or destabilization of cytoplasmic membrane integrity with a detergent-like effect. In several cases, membrane rupture causes bacteriocin to invade (Stevens et al., 1991). The main criteria for these types of mechanisms is the amphipathic nature of antimicrobial peptides, as hydrophobic regions are essential to interact directly with the lipid moieties of the membrane, while hydrophilic regions can bind with the phospholipid head groups or face the lumen of the pore. More ultrastructural studies on the morphological changes of the sensitive bacteria can through more light on the mode of action of these bacteriocins.

de Lima and Filho, (2005) proposed that the outer membrane acts as cell permeability barrier in Gram-negative bacteria but they can be sensitive to bacteriosins in the presence of chelating agents, hydrostatic pressure or cell damage. Hence peptides are inserted into the outer membrane through hydrophobic interactions or by prefolding of the peptides into a membrane-associated structure; which can cause membrane disruption enabling peptide entry, this process can be as termed self-promoted uptake. These processes enable the peptides to accumulate at the cytoplasmic membrane, gain entry into interfacial region of the membrane (the interface between the hydrophilic and hydrophobic portions of the membrane) in a process driven by electrostatic and hydrophobic interactions. The higher proportion of negatively charged lipids on the surface monolayer of the bacterial cytoplasmic membrane plays an important role in the selectivity of antimicrobial peptides for bacterial cells over eukaryotic cells, in which uncharged lipids predominate at the host cell surface. As a result, the peptide can permeabilize the membrane and/or translocate across the membrane and into the cytoplasm without causing major membrane disruption (Stevens et al., 1991).

Hence, the modes of action of antibacterial peptides can be broadly categorized as either membrane acting or non-membrane acting. While most cationic antibacterial peptides studied so far have been characterized as membrane permeabilizing, it should be noted that virtually any cationic amphiphilic peptide will cause membrane perturbation in model systems if a high enough concentration is applied, and there are few examples of studies with intact bacteria (Zhang et al., 2001; Patrzykat et al., 2002). Studies conducted with whole bacterial cells have revealed that several antibacterial peptides translocate into cells and do not cause membrane permeabilization but rather mediate bacterial cell death by targeting essential intracellular processes.

Bacteriocins are normally effective against gram positive bacteria belonging to closely related species and different genera (Moreno et al., 2000). Nisin and pediocin AcH are examples of bacteriocins owner of prominent antimicrobial spectrum which are able to exert inhibitory activity on the growth of bacteria such as L. plantarum, P. acidilactici, L. mesenteroides, L.monocytogenes and Micrococcus luteus (Ray, 1996). Regarding their narrow action, bacteriocins primary role is as intra-specific mediators or promoters of interactions among microbial populations (Cleveland et al.,2001). Microbial cell killing due bacteriocins action could occur as consequence of unbalanced cytoplasmic membrane function (affecting energy synthesis and permeability), inhibition of nucleic acid synthesis, interference on the protein synthesis and changing cell translator mechanism.

Bacteriocin producing-cells are immune to bacteriocin due to production of a protein (Hancock and Chapple, 1999). This makes them effective on competitor bacteria and not to the producing cell (Tadashi and Schnneewind, 1998). 
(A)

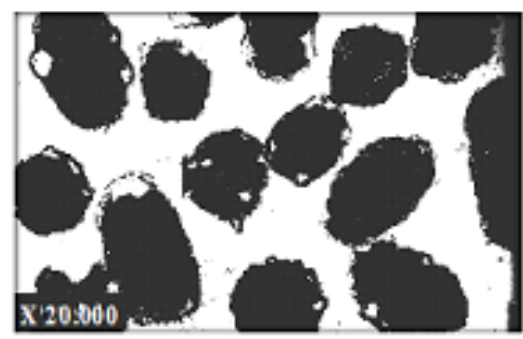

(B)

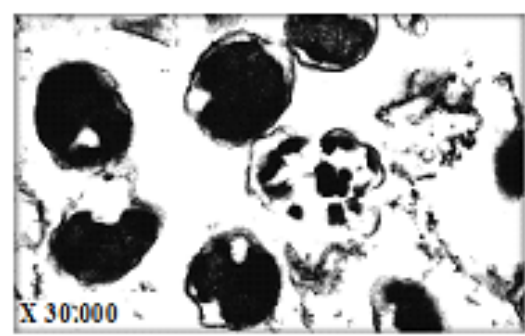

(C)

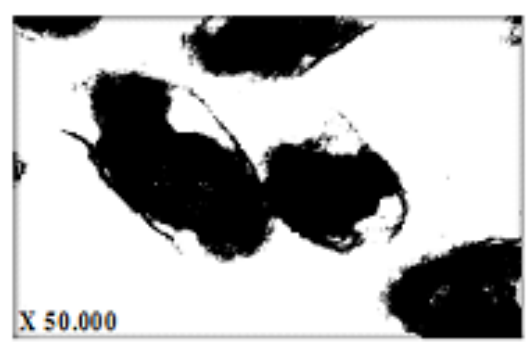

Fig. 2. Transmission electron micrographs (TEM) of S. typhimurium $\left(10^{5} \mathrm{CFU} / \mathrm{ml}\right)$. Control cells were left untreated a) or were treated with bacteriocin preparation of $B$. megaterium 19 b,c). Control cells remained as intact rod shape, while treated ones appeared as ghost cells with deformed morphology and distorted cell surface (Khalil et al., 2009).

\section{Toxicity and safety considerations}

Nisin, still remains an important bacteriocinal though several bacteriocins were characterized and developed for potential use (Chikindas and Montville, 2002). A comprehensive literature search shows that most of the information regarding the safety of nisin was collected over 35-37 years ago (Claypool et al., 1966; Shtenberg, 1973). It is likely that more information regarding nisin safety exists, but is not available to the public. Patents claiming nisin as an antibacterial agent in food, personal care products or for medical applications do not provide new data, and instead rely on previously published information (Blackburn et al., 1998; Cleveland et al., 2001). Purified nisin have been evaluated for toxicological effect and found harmless or at least with very low toxicity using rat and guinea pig models (Shtenberg and Ignatev, 1970). Nisin being used in over as food additive in 50 countries Nisin is legally approved for use canned soups (Australia), ice for storing fresh fish (Bulgaria), baby foods, baked goods and mayonnaise (Czech Re- public), and milk shakes (Spain) (Hurst and Hoover, 1993). In the U.S., use of nisin-producing starter cultures has never been regulated, as lactococci are considered GRAS (Generally regarded as safe). The safety of other bacteriocins with potential applications in food has also been evaluated. Pimiricin, a surface active antimycotic compound has also been approved (Henning et al., 1986). Morover, pediocin PA-1AcH was injected into mice and rabbits, and immunoblotting showed that it was non-immunogenic in both animals (Bhunia et al., 1990). The Food Safety and Inspection Service (FSIS) of the U.S. Department of Agriculture (USDA) evaluate the safety and effectiveness of bacteriocins in commodity segments such as meat and poultry products. Thus depending on the type of product, the food and drug administration (FDA) or FSIS approve use of novel bacteriocins before any applications are permitted (Chikindas and Montville, 2002).

\section{APPLICATIONS OF BACTERIOCINS}

\section{In clinical purposes}

Due toemergence of bacterial resistance to current antibiotic drugs interest has been growing in the development of antimicrobial peptides as a novel therapeutic approach to treat infections (Håvard et al., 2006). Several bacteriocins and peptides have been undergoing clinical trials, at various stages of development. Antimicrobial-peptide-based therapies are suitable alternate to antibiotics since they combat naturally the pathogens and possibility of resistance development is remote due to their mode of action. This has been proved by serial exposure at subinhibitory concentrations, (Ge et al., 1999; Zhang et al., 2005).Potential of developing peptides with multiple range of antibacterial, antiviral and antifungal activity is very high. 'Combination therapy' where antimicrobials could be used with existing drugs expressing synergistic effect has been used as followed in HIV treatment (De Clercq, 2004).

Currently two indolicidin-based antimicrobial peptide variants, MBI-226 and MX-594AN for the treatment of catheter-related infections and acne, respectively are under various clinical trials, awaiting for approval by concerned agencies. MX-594AN significantly reduced acne lesions. Iseganan abroad-spectrum antimicrobial failed in clinical trials to prevent or reduce oral mucositis compared with a placebo (Trotti et al., 2004). A variant of histatins, a natural cationic peptide was developed as mouth wash for treatment of oral candidiasis (Kavanagh and Dowd, 2004). The feasibility of developing antimicrobial peptides is very high due to the encouraging results obtained so far. Future prospects is bright to encounter the challenges for the peptide based therapies. Presently, peptides show ingno direct 
microbicidal activity in vitro are being developed to protect against bacterial infection or promote wound healing (Bowdish et al., 2005).

\section{In human health}

Bacteriocins provide an alternative solution to the use of antibiotics. The prospect of using bacteriocins as 'designer drugs' for specific bacterial pathogens is very high bacteriocin molecules may also be used treatment of cancer (Tanaka, 2001) and viral (Filatova et al., 2002) or parasitic infections (Vizioli andSalzet, 2003) due to their wide spectrum. A few biotechnological companies have developed bacterocins for various topical and systemic applications (Hancock and Diamond, 2000b).

\section{Bacteriocins in food systems}

Due to growing concern on the possible side adverse effects of chemical additives in food, interest is now focussed on use of bacteriocins as natural preservative with minimal food processing. Bacteriocins isolated from meat and dairy products have unknowingly been consumed for centuries, they. Among the gram-positive bacteria, the lactic acid bacteria have been comprehensively exploited as a reservoir for antimicrobial peptides with food applications. LAB produced bacteriocins have been used to ferment the products without any additional regulatory clearance as they are approved by FDA (Wessles et al., 1998; Montville and Winkowski, 1997).

\section{Biopreservation of dairy products}

Biopreservation refers to the use of antagonistic microorganisms or their metabolic products to inhibit or destroy undesired microorganisms in foods to enhance food safety and extend shelf life (Schillinger et al., 1996). Bacteriocins, produced by LAB, may be considered natural preservatives or biopreservatives that fulfill these requirements. Three approaches are commonly used in the application of bacteriocins for biopreservation of foods:

- Inoculation of food with LAB with ability to grow and produce bacteriocin

- $\quad$ Addition of purified or semi-purified bacteriocins as food preservatives.

- Use of a product previously fermented with a bacteriocin producing strain as an ingredient in food processing.

Nisin is being in 50 countries as a biopreservative including pasteurized foods. Nisin has many applications and is approved for use in various foods throughout the world (Table 3). L. monocytogenes has been the cause for anumber of outbreaks associated with dairy products, such as

Table 3. Examples of world wide use of nisin (Fleming et al., 1985)

\begin{tabular}{lll}
\hline Country & Food in which nisin is permitted & Maximum level (IU/g)* \\
\hline Argentina & Processed cheese. & 500 \\
Australia & Cheese, processed cheese, canned tomatoes. & No limit \\
Belgium & Cheese. & 100 \\
Cyprus & Cheeses, dotted cheese, canned vegetables. & No limit \\
EU & E234 may also be labeled as “natural preservative". & Varies according to product and member state. \\
France & Processed cheese. & No limit. \\
Italy & Cheese. & 500 \\
Mexico & Nisin is a permitted additive. & 500 \\
Netherlands & Factory cheese, processed cheese, cheese powder. & 800 \\
Peru & Nisin is a permitted additive. & No limit. \\
Russia & Diabetic processed cheese, canned vegetables. & 8000 \\
UK & Cheese, canned foods, clotted cream. & No limit. \\
US & Pasteurized processed cheese spreads. & 10.000
\end{tabular}

*International unit per gram. 
pasteurized milk (Fleming et al., 1985) and cheese (James et al., 1985), and nisin has been shown effective against L. monocytogenes in dairy products. Zottola et al. (1994) used Nisin-containing cheddar cheese and nissin added processed cheese (to prevent growth of Clostridium tyrobutyricum had been in vogue for several years (Zottola et al., 1994; Schillinger et al., 1996)

\section{Biopreservation of meat products}

The ability to grow at refrigeration temperatures and anaerobic conditions make L.monocytogenes, a highly potent pathogen and rigid policies of US government for its zero tolerance in ready to eat food, (Jay, 1996; Ryser and Marth, 1999) has lead to several studies to control $L$. monocytogenes in meat products on raw meat and cooked and ready-to-eat meat products (Ryser and Marth, 1999). Nisin in combination with lactic acid showed an increased effect as a preservative to inhibit gram negative organisms (Ariyapitipun et al.,1999 and 2000). Antilisterial activity of nisin A and pediocin ACH, enterocin CCM 4231 for controlling $L$. monocytogenes and sakacin $\mathrm{K}$ against $L$. innocua have given promising results (Murray and Richard,1997; Lauková et al. 1999). Nielsen et al. (1990) obtained promising results for the preservationof fresh meats using pediocin PA-1 produced by $P$. acidilactici

\section{Biopreservation of seafood products}

The bacteriocins are effective $\mathrm{s}$ to control growth of L. monocytogenes in vacuum-packed sea food and Katla et al. (2001) examined the effective inhibition of sakacin $\mathrm{P}$ and/or L. saké cultures (sakacin P producer) to L. monocytogenes contaminating cold-smoked salmon. Nisin in combination with carbon dioxide and low temperature showed inhibitory effect on the L. monocytogenes in cold-smoked salmon (Nilsson et al., 1997).

The effectiveness of nisin Z, carnocin UI49, and a preparation of crude bavaricin A on shelf life extension of brined shrimp was evaluated by Einarsson and Lauzon (1995) and considered as potential technology to prevent use of sorbic and benzoic acids. However, bacteriocins are still used a little in food conservation (de Souza et al., 2005).

\section{Bacteriocins in packaging film}

Antimicrobial packaging film prevents microbial growth on food surface by direct contact of the package with the surface of foods, such as meats and cheese without lost or reduction of antimicrobial activity(Chen and Hoover, 2003) and is advantageous than spraying or dipping of (Appendini and Hotchkiss, 2002). Bacteriocins are either incorporated into packaging films directly or (eg. nisin in biodegradable protein films) or to coat or adsorb bacteriocins on packaging films (eg nisin/methylcellulose coatings for polyethylene films and nisin coatings for poultry)(Padgett et al., 1998;Appendini and Hotchkiss, 2002).

\section{Use of bacteriocins in hurdle technology}

Hurdle technology is a combination of several preservation methods to retard microbial growth. Leistner,(2000). Reviewed the principles underlying hurdle technology, as well as potential hurdles in food systems. As shown in Table 4 the bacteriocins often have synergies with other treatments, and can be used as a hurdle to improve the safety of food. An understanding of the mode of action of each individual hurdle allows the most effective combination of treatments. The application of pulsed electric field (PEF), which increases the permeability of cell membranes, and metal chelators with EDTA in combination with nisin for the control of Salmonella and E. coli are a few examples of hurdle technologies (Terebiznik et al., 2000) \(Stevens et al., 1991) Zhang and Mustapha, 1999), probably EDTA disrupts the outer membrane, allowing the penetration of nisin (Abee et al., 1995).

\section{ACKNOWLEDGEMENT}

This study work was supported by the Laboratory of Microbiology, Biology Department, Mascara University, Algeria. 
Table 4. Increased activity of bacteriocins used as a part of hurdle technology (Leistner, 2000)

\begin{tabular}{|c|c|c|}
\hline Bacteriocin & Other factors & Effect \\
\hline Nisin A & $\mathrm{N}_{2} ; \mathrm{CO}_{2} ;$ low temperature & $\begin{array}{l}\text { Effect on L. monocytogenes: increase in the lag phase (400 IU } / \mathrm{ml}) \text {; } \\
\text { inhibition of growth }(1250 \mathrm{IU} / \mathrm{ml}) \text {. }\end{array}$ \\
\hline Pediocin $\mathrm{AcH}$ & $\begin{array}{l}\text { Hydrostatic pressure and high tempera- } \\
\text { ture }\end{array}$ & $\begin{array}{l}\text { Combination of pressure }(345 \mathrm{MPa}) \text {, temperature }\left(50^{\circ} \mathrm{C}\right) \text { and bacteri- } \\
\text { ocin acts synergistically causing reduction of viability of } S \text {. aureus, } L \text {. } \\
\text { monocytogenes, E. coli } \mathrm{O} 157: \mathrm{H} 7, \text { L. saké, L. mesenteroides. }\end{array}$ \\
\hline Nisin A & $\begin{array}{l}\text { Milk lactoperoxidase (LP) and low } \\
\text { temperature }\end{array}$ & $\begin{array}{l}\text { Nisin-producing } L \text {. lactis acts synergistically with LP in reduction of } L \text {. } \\
\text { monocytogenes. }\end{array}$ \\
\hline Nisin A & Calicium alginate gel & $\begin{array}{l}\text { Gel-immobilized nisin is delivered more effectively than pure nisin and } \\
\text { suppresses growth of Bro.thermosphacta on beef carcasses. }\end{array}$ \\
\hline Pediocin AcH & Sodium diacetate & $\begin{array}{l}\text { Combination of pediocin and sodium diacetate works synergistically } \\
\text { against } L \text {. monocytogenes both at room and low temperature. }\end{array}$ \\
\hline Nisin & Sucrose fatty acid esters & $\begin{array}{l}\text { Synergy against } L . \text { monocytogenes, B. cereus, L. Plantarum and } S \text {. } \\
\text { aureus. }\end{array}$ \\
\hline Nisin & Carbon dioxide & $\begin{array}{l}\text { Synergistic when used against wild-type and nisin-resistant } L . \text { monocy- } \\
\text { togenes. }\end{array}$ \\
\hline Nisin & Pulsed electric field & Synergistic activity against $B$. cereus. \\
\hline Nisin & Modified atmosphere packaging (MAP) & $\begin{array}{l}\text { Combination was more effective than either treatment alone at prevent- } \\
\text { ing growth of L. monocytogenes. }\end{array}$ \\
\hline Pediocin $\mathrm{AcH}$ & $\begin{array}{l}\text { Emulsifier (Tween } 80 \text { ) or encapsulation } \\
\text { of the pediocin within liposomes. }\end{array}$ & $\begin{array}{l}\text { Pediocin AcH possesses higher listericidal activity in slurries of nonfat } \\
\text { milk, butterfat, or meat when present in encapsulated form or acts in the } \\
\text { presence of Tween } 80 \text {. }\end{array}$ \\
\hline
\end{tabular}

\section{REFERENCES}

Abee T, Krockel L, Hill C. 1995. Bacteriocins: Modes of action and potentials in food preservation and control of food poisoning. Int J Food Microbiol. 28: 169-185.

Abrahan AML, Gomez ALB, Andrew CF. 1996. Aislamento de dermatófitos a partir de ninos sin signos clínicos de dermatofitoses. RevMed Tropica.

Alatossva T. 1994. Analogies between superinfection exclusion and bacteriocin immunity. Trends Microbiol. 2: 215-216.

Allgaier H, Jung G, Werner GG, Schneider U, Zahner H. 1986. Epiderminisequencing of a heterotetracyclic 21-peptide amide antibiotic. Eur JBiochem. 160: 9-22.

Allison G, Fremaux CA, Klaenhammer TR. 1994. Expansion of the bacteriocin activity and host range upon complementation of two peptides encoded within the lactacin F operon. J Bacteriol. 176: 2235-2241.
Altena K, Guder A, Cramer C, Bierbaum G. 2000. Biosynthesis of the lantibiotic mersacidin: organization of a type B lantibiotic gene cluster. Appl Environ Microbiol. 66: 2565-2571.

Amato Neto V, Levi GC, Lopes HV. 1994. Antibioticos na Pratica Medica. Sao Paulo, Roca.

Appendini P, Hotchkiss J. 2002. Review of antimicrobial food packaging. Innov Food Sci Emerg Technol. 3: $113-126$.

Ariyapitipun T, Mustapha A, Clarke AD. 1999. Microbial shelf life determination of vacuum-packaged fresh beef treated with polylactic acid, lactic acid, and nisin solutions. J Food Prot. 62: 913-920.

Ariyapitipun T, Mustapha A, Clarke AD. 2000. Survival of Listeria monocytogenes Scott A on vacuum-packaged raw beef treated with polylactic acid, lactic acid, and nisin. J Food Prot. 63: 131-136. 
Banerjee S, Hansen JN. 1988. Structure and expression of a gene encoding the precursor of subtilin, a small protein antibiotic. J Biol Chem. 263: 9508-9514.

Barefoot SF, Klaenhammer TR. 1984. Purification and characterization of the Lactobacillus acidophilus bacteriocin lactacin B.Antimicrob Agents Chemoter. 26: $328-334$.

Becker RJ, Cooper AJ, Starzyka MJ. 1993. Evidence for association of bacteriocinogenic activity with membrane vesicles of Thermus rubens. Microbios. 73: 123-133.

Bhunia AK, Johnson MC, Ray B, Belden EL. 1990. Antigenic property of pediocin $\mathrm{AcH}$ produced by Pediococcus acidilactici H. J Appl Bacteriol. 69: 211215.

Blackburn P, Polak J, Gusi S, Rubino S. 1998. Nisin compositions for use as enhanced broad range bactericides. Int Patent Appl WO, pp. 8911-2399.

Boemare NE, Boyer Giglio MH, Thaler JO, Akhust RJ, Behelin M. 1992. Lysogeny and bacteriogeny in Xenorhabdus nematophilus and other Xenorhabdus spp. Appl Environ Microbiol. 58: 3032-3037.

Boulnois GJ, Paton JC, Mitchell TJ, Andrew PW. 1991. Structure and function of pneumolysin, the multifunctional, thiol-activated toxin of Str. pneumoniae. Mol Microbiol. 5: 2611-2616.

Bowdish DM, Davidson J, Lau YE, Lee K, Scott MG, Hancock RE. 2005. Impact of LL37 on anti-infective immunity. J Leuk Biol. 77: 451-459.

Bradley DE. 1966. The structure of pyocin particles released from Pseudomonas aeruginosa by mitomycin C. Int Cong Electr Microscop. 6: 115-116.

Bradely D. 1967. Ultrastructure of bacteriophage abd bacteriocins. Bacteriol Rev. 31: 230-314.

Brashears M, Reilly S, Guilland SE. 1998. Antagonistic action of cells of Lactococcus lactis toward Escherichia coli $\mathrm{O} 157: \mathrm{H} 7$ on refrigerated raw chicken meat. J Food Prot. 61: 166-179.

Braun V, Pils1 H, Grob P. 1994. Colicins: structures, modes of actions, transfer through membranes, and evolution. Arch Microbiol. 161: 199-206.
Brock TD. 1995. Biology of microorganisms. New Jersey, Prentice Hall.

Chatterjee S, Chatterjee DK, Jani RH, Blumbach J, Ganguli BN, Klesel N, Limbert M, SeibertG. 1992a. Mersacidin, a new antibiotic from Bacillus. In vitro and in vivo antibacterial activity. J Antib. 45 (39): 839-845.

Chatterjee S, Chatterjee DK, Lad SJ, Phansalkar MS, Rupp RH, Ganguli BN, Fehlhaber HW, Kogler H. 1992b. Mersacidin, a new antibiotic from Bacillus. fermentation, isolation, purification and chemical characterization. J Antib. 45: 832-838.

Chen H, Hoover DJ. 2003. Bacteriocins and their food applications. Compreh RevFood SciFood Saf. 2(3): 82-100.

Cheung J, Danna K, O’Connor E, Price L, Shand R. 1997. Isolation, sequence, and expression of the gene encoding halocin $\mathrm{H} 4$, a bacteriocin from the halophilic archaeon Haloferax mediterranei R4. J Bacteriol. 179: $548-551$

Chikindas ML, Montville TJ. 2002. Perspectives for application of bacteriocins as food preservatives. In:Juneja VK,Sofos JN Eds. Control of food borne microorganisms. New York:Marcel Dekker. Inc, pp. 303-321.

Cintas LM, Casaus P, Holo H, Hernandez PE, Nes IF, Harvastein LS. 1998. Enterocins L50A and L50B, two novels bacteriocins from Enterococcusfeacium L50, are related to staphylococcal hemolysins. $J$ Bacteriol. 180: 1988-1994.

Claypool L, Heinemann B, Voris L, Stumbo CR. 1966. Residence time of nisin in the oral cavity following consumption of chocolate milk containing nisin. J Sci. 49: 314-316.

Cleveland J, Mantiville TJ, Ness IF, Chiknids L. 2001. Bacteriocins: safe antimicrobials for food preservation. Int J Food Microbiol. 71: 1-20.

Davis I. 1999. What are antibiotics? Archaic functions for modern activities. Mol Microbiol. 4: 1227-1232.

Daw MA. 1989. Ph.D thesis. Dublin University. Trinity College Dublin. Ireland. 
Daw MA, Falkiner FR. 1993. The ultrastructure of cloacin C5 of Enterobacter cloacae. Proc Royal Microscopical Soc. 28: 24.

Daw MA, Fredrick RF. 1996. Bacteriocins: nature, function and structure. Micron. 27: 467-479.

De Clercq E. 2004. Antiviral drugs in current clinical use. $J$ Clin Virol. 30: 115-133.

de Lima ET, Filho RL. 2005. Bacteriocins: nomenclature, detection, mechanism of action and potential use in poultry production. J Food Agric Environ. 3: 62-66.

de Souza EL, Clemilson A, de Sousa1 CP. 2005. Bacteriocins: Molecules of fundamental impact on the microbial ecology and potential food biopreservatives. Braz Arch Biol Technol. 48: 559-566.

De Vuyst L, Vandamme EJ. 1994. Antimicrobial potential of lactic acid bacteria. pp 91-142. In: De Vuyst L, Vandamme EJ, Eds. Bacteriocins of lactic acid bacteria. Blackie Academic and Professional, Glasgow.

Diep DB, Havarstein LS, Nes IF. 1996. Characterization of the locus responsible for the bacteriocin production in Lactobacillus plantarum C11. J Bacteriol. 178: 4472-4483.

Diep DB, Havarstein LS, Nissen-Meyer J, Nes IF. 1994. The gene encoding plantaricin A, a bacteriocin from Lactobacillus plantarum $\mathrm{C} 11$, is located on the same transcription unit as an agr-like regulatory system. Appl Environ Microbiol. 60: 160-166.

Dykes GA. 1995. Bacteriocins: ecological and evolutionary significance. Trends Ecol Evol. 10: 186-189.

Ehrman MA, Remiger A, Eijsink VG, Vogel RF. 2000. A gene cluster encoding plantaricin 1.25 beta and other bacteriocin like peptides in Lactobacillus plantarum TMW 125. Biochem Biophys Art. 1490: 355-361.

Einarsson H, Lauzon HL. 1995. Biopreservation of brined shrimp (Pandalus-borealis) by bacteriocins from lactic-acid bacteria. Appl Environ Microbiol. 61: 669676.

Engelke G, Gutowski-Eckel Z, Hammelmann M, Entian KD. 1992. Biosynthesis of the lantibiotic nisin: genomic organization and membrane localization of the NisB protein. Appl Environ Microbiol. 58: 37303743 .
Engelke G, Gutowskieckel Z, Kiesau P, Siegers K, Hammelman M, Entian KD. 1994. Regulation of nisin biosynthesis and immunity in Lactococcus lactis 6F3. Appl Environ Microbiol. 60: 814-825.

Ennahar S, Sashihara T, Sonomoto K, Ishizaki A. 2000. Class IIa bacteriocins:biosynthesis structure and activity. FEMS Microbiol Rev. 24: 85-106.

Ferrer S, Viejo MB, Guasch JF, Enfedaque J, Regue M. 1996. Genetic evidence for an activator required for induction of colicin-like bacteriocin $28 \mathrm{~b}$ production in Serratia marcescens by DNA-damaging agents. Amer Soc Microbiol. 178: 951-960.

Filatova NA, Anikin VB, Platonov VG, Bulet P. 2002. Antiviral and antitumor peptides from insects. Proc Nat Acad Sci. 99:12628-12632.

Fleming DW, Cochi SL, MacDonald KL, Brondum J, Hayes PS, Plikaytis BD, Holmes MB, Audurier A, Broome CV, Reingold AL. 1985. Pasteurized milk as avehicle of infection in an outbreak of listeriosis. New Engl J Med. 312: 404-407.

Florey HW. 1996. The use of microorganisms for therapeutic structure. Micron. 27: 467-479.

Fredericq P. 1957. Colicins. Ann Revi Microbiol. 11: 7-22.

Fredericq P. 1963. On the nature of colicinogenic factors: a review. J Theoric Biol. 4: 159-161.

Ganz T. 2003. Defensins: antimicrobial peptides of innate immunity. Nat RevImmunol. 3: 710-720.

Ge Y, MacDonald DL, Holroyd KJ, Thornsberry C, Wexler H, Zasloff M. 1999. In vitro antibacterial properties of pexiganan, an analog of magainin. Antimicrob Agents Chem. 43: 782-788.

Gratia A. 1925. Comptes Rendus des Seances de la Société de Biology. 93: 1040-1041. In: Mayr-Harting and others. (1972).

Guder A, Wiedemann I, Sahl HG. 2000. Post-translationally modified bacteriocins-the lantibiotics. Biopolymers 55: $62-73$.

Hancock RE, Chapple DS. 1999. Peptides antibiotics. Antimicrobial agents and Chemotherapy. 43: 13171323. 
Hancock E, Diamond W. 2000a. Cationic antimicrobial peptides: towards clinical applications. Exp Opin Inves Drugs. 9:1723-1729.

Hancock RE, Diamond G. 2000b. The role of cationic antimicrobial peptides in innate host defences. Trends Microbiol. 8: 402-410.

Hancock RE, Rozek A. 2002. Role of membranes in the activities of antimicrobial cationic peptides. FEMS Microbiol Lett. 206: 143-149.

Hansen JN. 1993. Antibiotics synthesized by post translational modification. Ann Rev Microbiol. 47: 535-564.

Hardy KG. 1975. Colicinogeny and related phenomena. Bacteriol Rev. 39: 464-515.

Hardy KG, Meynell GC. 1972a. Colicin factors and mitomycin. J Gen Microbiol. 73: 547-549.

Hardy KG, Meynell GC. 1972b. Induction of colicin factor E2-P9 by mitomycin. J Bacteriol. 112: 1007-1009.

Håvard J, Pamela H, Robert EWH. 2006. Peptide Antimicrobial Agents. Clin Microbiol Rev. 19: 491511.

Havarstein LS, Holo H, Nes IF. 1994. The leader peptide of colicin $\mathrm{V}$ shares consenus sequence with leader peptides that are common among peptide bacteriocin produced by gram positive bacteria. Microbiol. 140: 2383-2389.

Henning S, Metz R, Hammes WP. 1986. New aspects for the application of nisin to foods based on its mode of action. Int J Food Microbiol. 3: 135-142.

Howards P, Cavard D, Lazdunski C. 1989. Amino acid sequence and length requirements for assembly and function of the colicin A lysis protein. $J$ Bacteriol. 171: $410-418$.

Hurst A. 1978.Nisin: its preservative effect and function in the growth cycle of the producer organism. Soc Appl Bacteriol Sympos Series. 7: 297-314.

Hurst A, Hoover DG. 1993. Nisin. pp. 237-274. In: Davidson PM, John NS, Branen AL Eds. Antimicrobials in foods.

Issacson RE, konisky J. 1974. Studies on the regulation of the colicin Ib synthesis: replication of the Co1Ib-P9 plasmid during colicin induction. Antimicrob Agents Chem. 6: 848-852.
Ito S, Kageyama M. 1970. Relationship between pyocins and a bacteriophage in pair. J Gen Appl Microbiol. 16: 231-240.

Ito S, Kageyama M, Egami F. 1970. Isolation and characterization of pyocins from several strains of Pseudomonas aeruginosa. J Appl Microbiol. 16: 205-214.

Jack RW, Tagg JR, Ray B. 1995. Bacteriocins of gram positive bacteria. Microbiol. 59: 171-200.

Jacob F, Siminovitch L, Wollman E. 1952. Sur la biosynthese d'une colicine et sur son mode d'action. Ann Inst Pasteur. 83: 295-315.

James SM, Fannin SL, Agee BA, Gall B, Parker E, Vogt J, Run G, Williams J, Lieb L, Prendergast T, Werner SB, Chin J. 1985. Listeriosis outbreak associated with Mexican-style cheese. California. Morb Mort W Rep. 34: 356-357.

James R, Lazdunski C, Pattus F. 1991. Bacteriocins, microcins and lantibiotics.

James R, Kleanthous C, Moore GR. 1996. The biology of E-colicins: paradigms and paradoxes. Microbiol. 142: 1569-1580.

Jay JM. 1996. Modern food microbiology. Inc, 635. pp.

Jensen H, Hamill P, Hancock RE. 2006. Peptides antimicrobial agents. Clini Microbiol Rev. 19: 491-51.

Joerger MC, Klaenhammer TR. 1986. Characterization and purification of helveticin $\mathrm{J}$ and evidence for a chromosomally determined bacteriocin produced by Lactobacillus helveticus 481. J Bacteriol. 167: 439446.

Jon Nissen M, IngolfFN. 1997. Ribosomally synthesized antimicrobial peptides: their function, structure, biogenesis, and mechanism of action. Arch Microbiol. 167: $67-77$.

Jung G. 1991. Lantibiotics: ribosomally synthesized biologically active polypeptides containing sulfide bridges and a, b didehydroamino acids. Angew Chem Int Ed Ingl .30:1051-1068.

Jung G, Sahl HG. 1991. Lantibiotics: a survey. pp 1-34. In: Nisin and Novel. Lantibiotics. Leiden, Netherlands.

Kaletta C, Entian KD, Jung G. 1991. Prepeptide sequence of cinnamycin (Ro 09-0198): the first structural gene 
of a duramucin - type lantibiotic. Eur J Biochem. 199: 411-415.

Katla T, Møretrø T, Aasen IM, Holck A, Axelsson L, Naterstad K. 2001. Inhibition of L. monocytogenes in cold smoked salmon by addition of sakacin $\mathrm{P}$ and/or live Lactobacillus saké cultures. Food Microbiol. 18: 431-9.

Kavanagh K, Dowd S. 2004.Histatins: antimicrobial peptides with therapeutic potential. J Pharm Pharmacol. 6: $285-289$.

Khalil R, Elbahloul Y, Djadouni F, Omar S. 2009. Isolation and partial characterization of bacteriocin produced by a newly isolated Bacillus megaterium 19 strain. PakJ Nutr. 8: 242-250.

Kingsbury D. 1966. Bacteriocin production by strains of Neisseria meningitidis. J Bacteriol. 91: 1696-1699.

Klaenhammer TR.1988. Bacteriocins of lactic acid bacteria. Biochem. 70: 337-349.

Klaenhammer TR. 1993. Genetics of bacteriocins produced by lactic acid bacteria. FEMS Microbiol Rev. 12: 39-86.

Klein C, Entian KD. 1994. Genes involved in self-protection against the lantibiotic subtilin produced by Bacillus subtilis ATCC6633. Appl Environ Microbiol. 60: 2793-2801.

Klein C, Kaletta C, Entian KD. 1993. Biosynthesis of the lantibiotic subtilin is regulated by a histidine kinase/ response regulator system. Appl Environ Microbiol. 59: 296-303.

Klein C Kaletta, C, Schnell N, Entian KD. 1992. Analysis of genes involved in biosynthesis of the lantibiotic subtilin Appl Environ Microbiol. 58: 132-142.

Klement Z, Rodolph K, Sands DC. 1990. Methods in phytobacteriology and Bacteriocins. Akademiai Kiado, Budapest, Hungary, pp. 245-249.

Koebink R, Braun V. 1993. Insertion derivatives containing segments of up to 16 amino acids identify surface and periplasm exposed regions of the outer memberane receptor of Escherichia coli K-12. J Bacteriol. 3: 826-839.

Konisky R, Richard SF. 1970. Characterisation of colicin Ia and colicin Ib. J Biol Chem. 245: 2972-2978.
Kozak W, Bardowski J, Dobrzanski WT. 1977. Lacstrepcina bacteriocin produced by Streptococcus lactis. Bull Acad Polon Sci [Biol]. 25: 217-221.

Kozar W, Bardowski JE, Dobrzanski WT. 1978. Lactostrepcins-acid bacteriocins produced by lactic Streptococci. J Res. 45: 247-257.

Kruszewska D, Sahl HG, Bierbaum G, Pag U, Hynes SO, Ljungh A. 2004. Mersacidin eradicates methicillinresistant Staphylococcus aureus (MRSA) in a mouse rhinitis model. J Antimicrob Chem. 54: 648-653.

Kupke T, Gotz F. 1996. Post-translational modifications of lantibiotics. Antonie van Leeuwenhoek. 69: 139-150.

Lakey JH, Duche D, Gonzalez-Manas JM, Baty D, Pattus F. 1993. Flouresence energy transfer distance measurements the hydrophopic helical hairpin of colicin A in the membrane bound state. J Mol Biol. 230: 10551067.

Laukova A, Czikkova S, Laczkova S, Turek, P. 1999. Use of enterocin CCM 4231 to control Listeria monocytogenes in experimentally contaminated dry fermented Hornád salami. Int J Food Microbiol. 52:115-119.

Lebek G, Teysseire P, Baugartner A. 1993. A method of typing Listeria monocytogenes strains by classification of listeriocin and phage receptors. Int J Food Microbiol Virol Parasitol Infec Diseases 278: 58-65.

Leistner L. 2000. Basic aspects of food preservation by hurdle technology. Int J Food Microbiol. 55: 181-186.

Lewus CB. 1991. Characterization of bacteriocins produced by lactic acid bacteria isolated from meat. Appl Environ Microbiol, 153 pp.

Lewus CB, Sun S, Montville TJ. 1992. Production of an amylase sensitive bacteriocin by an atypical Leuconostoc paramesenteroides strain. Appl Environ Microbiol. 58: 143-149.

Marugg JD, Gonzalez CF, Kunka BS, Ledeboer AM, Pucci MJ, Toonen MY, Walker SA, Zoetmulder LC, Enbergh PA. 1992. Cloning, expression, and nucleotide sequence of genes involved in production of pediocin A-1, and bacteriocin from Pediococcus acidilactici PAC1.0. Appl Environ Microbiol. 8: 2360-7.

Mattick ATR, Hirsch A. 1947. Further observations on an inhibitory substance (nisin) from lactic Streptococci. Lancet. 11: 5-7. 
Mattick ATR, Hirsch A. 1944. A powerful inhibitory substance produced by group N Streptococci. Nature 154: $550-551$.

McAuliffe O, Ross RP, Hill C. 2001. Lantibiotics: structure, biosynthesis and mode of action. FEMS Microbiol Rev. 25: 285-308.

McCormick EM, Savage DC. 1983. Characterization of Lactobacillus sp. strain 100-37 from murine gastrointestinal tract. Ecology, plimid content, and antagonistic activity toward Clostridium raumrim $\mathrm{H} 1$. Appl Environ Microbiol. 46: 103-102.

Montville TJ, Kaiser A. 1993. Antimicrobial proteins: classification nomenclature, diversity and relationship to bacteriocins. pp. 1-22. In: Hoover DG, Steenson LR (Eds.) Bacteriocins of lactic acid bacteria. Academic Press.

Montville TJ, Winkowski K. 1997. Biologically based preservation systems and probiotic bacteria. In:Doyle MP, Beuchat LR, Montville TJ (Eds.) Food Microbiol, ASM Press, pp. 57-77.

Montville TJ, Winkowski K, Lusdescher RD. 1995. Models and mechanisms for bacteriocin action and application. Int J. 5: 797-814.

Montville TJ, Chung HJ, Chikindas MI, Chen Y. 1999. Nisin A depletes intracellular ATP and acts in a bactericidal manner against Mycobacterium smegmatis. Lett Appl Microbiol. 28: 189-193.

Moreno I, Learyer ALS, Leitao MF. 2000. Detection and characterization of bacteriocins producing of Lactococcus lactis strains. Braz J Microbiol. 31: 184192.

Morris SL, Walsh RC, Hansen JN. 1984. Identification and characterization of some bacterial membrane sulphydryl groups which are targets of bacteriostatic and antibiotic action. J Biol Chem. 259: 13590-13594.

Murray M, Richard JA. 1997. Comparative study of the antilisterial activity of nisin $\mathrm{A}$ and pediocin $\mathrm{AcH}$ in fresh ground pork stored aerobically at $5^{\circ} \mathrm{C}$. J Food Prot. 60: 1534-1540.

Nes IF, Tagg JR. 1996. Novel lantibiotics and their prepeptides. Antonie van Leeuwenhoek. 69: 89-97.

Nes IF, Diep DB, Havarstein LS, Brurberg MB, Eijsink V, Holo H. 1996. Biosynthesis of bacteriocins in lactic acid bacteria. Antonie van Leeuwen hoek. 70:113128.

Nissen-Meyer J, Nes IF. 1997. Ribosomally synthesized antimicrobial peptides: their function, structure, biogenesis, and mechanism of action. Arch Microbiol. 167: $67-77$.

Nissen-Meyer J, Holo H, Håvarstein LS, Sletten K, Nes IF. 1992. A novel lactococcal bacteriocin whose activity depends on the complementary action of two peptides. J Bacteriol. 174: 5686-5692.

Nielsen JW, Dickson JS, Crouse JD. 1990. Use of a bacteriocin produced by Pediococcus acidilactici to inhibit Listeria monocytogenes associated with fresh meat. Appl Environ Microbiol. 56: 2142-2145.

Nieto-Lozano JC, Meyer JN, Sletten K, Pleaz C, Nes IF. 1992. Purification and amino acid sequence of a bacteriocin produced by Pediococcus acidilactici. J Gen Microbiol. 138:1985-1990.

Nilsson L, Huss HH, Gram L. 1997. Inhibition of Listeria monocytogenes on cold-smoked salmon by nisin and carbon dioxide atmosphere.Int J Food Microbiol. 38: 217-2797.

Nomura M. 1967. Colicins and related bacteriocins. Ann Rev Microbiol. 12: 257-284.

Oscariz P. 2001. Classification and mode of action of membrane active bacteriocins produced by gram positive bacteria. Int Microbiol. 4: 13-19.

Padgett T, Han I, Dawson P. 1998. Incorporation of foodgrade antimicrobial compounds into biodegradable packaging films. J Food Prot. 61: 1330-1335.

Patrzykat A, Friedrich CL, Hang LZ, Mendoza V, Hancock REW. 2002. Sublethal concentrations of pleurocidinderived antimicrobial peptides inhibit macromolecular synthesis in Escherichia coli. J Antimicrob Chem. 46: 605-614.

Pelczar M, Reid R, Chan ECS. 1980. Microbiology (4 Eds.). New Delhi. Microbiol.936 pp.

Price L, Shand R. 2000. Halocin S8: a 36-amino acid microhalocin from the haloarchaeal strain S8a. J Bacteriol. 182: 4951-4958. 
Pugsley AP. 1984a. Genetic analysis of ColN plasmid determinants for colicin production, release, and immunity. J Bacteriol. 158: 523-529.

Pugsley AP, Oudega B. 1987. Methods for studying colicins and their plasmids. In: Hardy KG Ed. Plasmids, a practical approach, pp. 105-161.

Qiao M, Ye S, Koponen O, Ra R, Usabiaga M, Immonen T, Saris PE. 1996. Regulation of the nisin operons in Lactococcus lactis N8. J Appl Bacteriol. 80: 626-634.

Rauch PJG, de Vos WM. 1992. Characterization of the novel nisin-sucrose conjugative transposon Tn5276 and its insertion in Lactococcus lactis.J Bacteriol. 174: $1280-1287$.

Ray B. 1996. Fundamental food microbiology. Washington. CRC Press.

Reeves P. 1965. The bacteriocins. Bacteriol Rev. 29: 2445.

Reeves P. 1972. The bacteriocins. In: Kleinzeller A, Springer GF, Wittmann HG Eds. Mol Biol Biochem Biophys. Springer-Verlag, New York. 11: 87-111.

Riley MA. 1998. Molecular mechanisms of bacteriocins evolution. Ann Rev Gen. 32: 255-278.

Riley MA, Gordon DM. 1992. A survey of col plasmids in natural isolates of Escherichia coli and an investigation into the stability of col-plasmid lineages. $J$ Microbiol. 138: 1345-1352.

Riley MA, Gordon DM. 1999. The ecological role of bacteriocins in bacterial competition. Trends Ecol Evol. 7: 129-133.

Riley MA, Wertz JE. 2002. Bacteriocins: evolution, ecology, and application. Ann Rev Microbiol. 56: 117-137.

Rogers LA. 1928. The inhibitory effect of Streptococcus lactis on Lactobacillus bulgaricus. J Bacteriol. 16: 321-325.

Ruiz-Barba JL, Cathcart DP, Warner PJ, Jimenez-DiazR. 1994. Use of Lactobacillus plantarum LPC010, a bacteriocin producer, as a starter culture in spanish-style green olive fermentations. Appl Environ Microbiol. 60: 2059-2064.

Ryser ET, Marth EH.1999. Listeria, listeriosis and food safety. New York. Marcel Dekker.Second (Ed.). 738 pp.
Sahl HG. 1994. Staphylococcin 1580 is identical to the lantibiotic epidermin. Implications for the nature of bacteriocins from gram-positive bacteria. Appl EnvironMicrobiol. 60: 752-755.

Sano Y, Kobayashi M, Kageyama M. 1993. Functional domains of S-type pyocins deduced from chimeric molecules. J Bacteriol. 175: 6179-6185.

Schillinger U, Geisen R, Holzapeel WH. 1996. Potential of antagonistic microorganisms and bacteriocins for the biological preservation of food. Trends Food Sci Technol. 7: 158-164.

Shand R, Price L, O’Connor EM. 1998. Halocins: protein antibiotics from hypersaline environments. In: Oren A (Ed.) Microbiology and Biogeochemistry of Hypersaline Environments. Boca Raton, FL: CRC. 24: 295-306.

Shtenberg AI. 1973. Toxicity of nisin. Food Cosm.

Shtenberg AJ, Ignatev AD. 1970. Toxicological evaluation of some combinations of food preservatives. Food CosmToxicol. 8: 369-380.

Siezen RJ, Kuipers OP, de Vos WM. 1996. Comparison of lantibiotic gene clusters and encoded proteins. Antonie van Leeuwenhoek 69: 171-184.

Stevens KA, Sheldon BW, Klapes NA, Klaenhammer TR. 1991. Nisin treatment for inactivation of Salmonella species and other gram-negative bacteria. Environ Microbiol. 57: 3612-3615.

Tadashi B, Schnneewind O. 1998. Instruments of microbial warfare: bacteriocin synthesis, toxicity and immunity. Trends Microbiol. 6: 66-71.

Tagg JR. 1992. Bacteriocins of gram-positive bacteria; an opinion regarding their nature, nomenclature, and numbers. In: James R, Lazdunski C, Pattus F Eds. Bacteriocins, microcins and lantibiotics, pp. 33-36.

Tagg JR, Dajani AS, Wannamaker LW. 1976. Bacteriocins of gram-positive bacteria. Bacteriol Rev. 40: 722-756.

Tanaka K. 2001. P-I3 - kinase p85 is a target molecule of proline-rich antimicrobial peptide to suppress proliferation of ras - transformed cells. J Cancer Res. 92: 959-967.

Tavares W. 1984. Manual de antibióticos. São Paulo, Atheneu. 
Taylor JI, Hirsch I, Mattick ATR. 1949. The treatment of bovine streptococcal and staphylococcal mastitis with nisin. Vet Rec. 61: 197-198.

Terebiznik MR, Jagus RJ, Cerrutti P, de Huergo MS, Pilosof AM. 2000. Combined effect of nisin and pulsed electric fields on the inactivation of Escherichia coli. $J$ Food Prot. 63: 741-746.

Terras FR, Schoofs HM, De Bolle MF, Van Leuven F, Rees SB, Vanderleyden J, Cammue BP, Broekaert WF. 1992. Analysis of two novel classes of plant antifungal proteins from radish (Raphanus sativus L.) seeds. J Biol Chem. 267: 15301-15309.

Torreblanca M, Meseguer I, Ventosa A. 1995. Production of halocin is a practically universal feature of archael halophilic rods. LettAppl Microbiol. 19: 201-5.

Tossi A, Sandri L. 2002. Molecular diversity in geneencoded, cationic antimicrobials polypeptides 8: $743-761$.

Trabulsi LR, Alterthum F, Gompertz OF, Candeias JAN. 2002. Microbiologia. São Paulo, Atheneu.

Trotti A, Garden A, Warde P, Symonds P, Langer C, Redman R, Pajak TF, Fleming TR, Henke M, Bourhis J, Rosenthal DI, Junor E, Cmelak A, Sheehan F, Pulliam J, Devitt-Risse P, Fuchs H, Chambers M, O'Sullivan B, Ang KK. 2004. A multinational, randomized phase III trial of iseganan $\mathrm{HCl}$ oral solution for reducing the severity of oral mucositis in patients receiving radiotherapy for head-and-neck malignancy. Int $J$ Rad Oncol BiolPhys 58: 674-681.

Tsai H, Bobek LA. 1998. Human salivary histatins: promising anti-fungal therapeutic agents. Crit Rev Oral Biol Med. 9: 480-497.

Upreti GC, Hinsdill RD. 1975. Production and mode of action of lactocin 27: Bacteriocin from homofermentative Lactobacillus. J Antimicrob Chem. 7: 139-45.

van Belkum MJ, Hayema BJ, Geis A, Kok J, Venema G. 1991. Organization and nucleotide sequences of 2 lactococcal bacteriocin operons. Appl Environ Microbiol. 57: 492-498.
Vaughan EE, Daly C, Fitzgerald GF. 1992. Identification and characterization of helveticin V-1829, a bacteriocin produced by Lactobacillus helveticus 1829. J Appl Bacteriol. 73: 299-308.

Venema K, Abee T, Haandrikman AJ, Leenhouts KJ, Kok J, Konings WN,Venema G. 1993. Mode of action of lactococcin B, a thiolactivated bacteriocin from Lactococcus lactis. Appl Environ Microbiol. 59: 1041-1048.

Vizioli J, Salzet M. 2003. Antimicrobial peptides: new weapons to control parasitic infections. Trends Parasitol. 19 pp.

Wessels S, Jelle B, Nes I. 1998. Bacteriocins of lactic acid bacteria. Toxicol. Denmark.

Whitehead HR. 1933. A substance inhibiting bacterial growth, produced by certain strains of lactic Streptococci. Biochem J. 27: 1793-1800.

Zasloff M. 1987. Magainins, a class of antimicrobial peptides from Xenopus skin: isolation, characterization of two active forms, and partial cDNA sequence of a precursor. Proc Nat Acad Sci. 84: 5449-5453.

Zasloff M. 2002. Antimicrobial peptides of multicellular organisms. Nature 415: 389-395.

Zhang S, Mustapha A. 1999. Reduction of Listeria monocytogenes and Escherichia coli O157:H7 numbers on vacuum packaged fresh beef treated with nisin or nisin combined with EDTA. J Food Prot. 62: 1123-1127.

Zhang L, Rozek A, Hancock RE. 2001. Interaction of cationic antimicrobial peptides with model membranes. $J$ Biol Chem. 276: 35714-35722.

Zhang L, Parente J, Harris SM, Woods DE, Hancock REW, Falla TJ. 2005. Antimicrobial peptide therapeutics for cystic fibrosis. Antimicrob Agents Chem. 49: 29212927.

Zottola EA, Yezzi TL, Ajao DB, Roberts RF. 1994. Utilization of cheddar cheese containing nisin as an antimicrobial agent in other foods. Int $\mathrm{J}$ Food Microbiol. 24: 227-238. 